\title{
Secondary Ligand Effects on the Cytotoxicity of Several Casiopeína's Group II Compounds
}

\author{
María Elena Bravo-Gómez, ${ }^{1}$ Silvia Dávila-Manzanilla, ${ }_{1}^{1}$ Jessica Flood-Garibay, ${ }^{1,2}$ Miguel Ángel Muciño- \\ Hernández, ${ }^{1}$ Ángel Mendoza, ${ }^{3}$ Juan Carlos García-Ramos, ${ }^{1}$ Rafael Moreno-Esparza, ${ }^{1}$ Lena Ruiz-Azuara*1 \\ ${ }^{1}$ Departamento de Química Inorgánica y Nuclear, Facultad de Química, Universidad Nacional Autónoma de México, Avenida \\ Universidad 3000, 04510, México D. F., México. Phone: +52(55)56223529; ruizazuara@gmail.com \\ 2 Departamento de Ciencias Químico-Biológicas. Escuela de Ingeniería y Ciencias. Universidad de las Américas-Puebla, Ex \\ hacienda Sta. Catarina Mártir S/N, 72810, Cholula, Puebla, Pue., México. \\ ${ }^{3}$ Centro de Química, ICUAP, Benemérita Universidad Autónoma de Puebla, 72570, Puebla, Pue., México.
}

Dedicated to Dr. Estela Sánchez de Jiménez for her invaluable contributions to plant biochemistry

Received May 19, 2011; accepted December 14, 2011

\begin{abstract}
The aim of this study is to identify the influence of the ligand aminoacidato on the antiproliferative activity against human tumor cell lines HeLa, HCT-15 and SKL-U through the analysis of a set of $\mathrm{Cu}(\mathrm{II})$ coordination compounds with general formula $[\mathrm{Cu}(4,7-$ dimethyl-1,10-phenanthroline) $(\mathrm{N}-\mathrm{O})] \mathrm{NO}_{3}$ where $\mathrm{N}-\mathrm{O}$ represents several essential aminoacids. Results show that the hydrophobicity of the amino acid ligands increases the cellular uptake of copper (II) in HeLa tumor cell line, however, the increase of copper concentration inside the cell is not enough to produce significant changes in antiproliferative activity in this tumor cell line. Thus, the substituents on diimine ligand apparently play the stronger role to control the activity of these complexes. Also molecular structures of compounds 2 (Cas IIala) and 4 (Cas IInva) are presented.
\end{abstract}

Key words: Copper, mixed chelate, aminoacids, ligand effect, inorganic anticancer compounds, cytotoxicity, intracellular distribution.

\section{Introduction}

In the last decades metal complexes have gained a growing interest as pharmaceuticals for their use as diagnostic agents or as chemotherapeutic drugs [1-4]. In this field, one of the main goal is the development of non-platinum compounds with antineoplastic activity through modes of action different from that of cisplatin (coordinated to DNA), for example, Sn(IV) [5], Ti(IV) [6], V [6], $\mathrm{Au}(\mathrm{IIII})$ [7], Ru(II) [8], Pd(II) [9], Rh(I) [10] and $\mathrm{Cu}$ (II) [11-13] compounds, involve non-traditional interaction with DNA or other biological targets as mitochondria. These new molecules have to fulfil several requirements in preclinical and clinical studies in their way to clinical phases, such as to reduce the toxicity; increase activity compared with known compounds, proved activity on cell lines resistant to known treatments and have preferentially low production costs.

Currently, several groups of copper complexes in both oxidation states (I) and (II) have been studied as potential antitumor agents [12-15]. Copper is an essential trace element important for the function of several enzymes involved in energy metabolism, respiration and DNA synthesis in the cell $[16,17]$, and the major functions of biological-active copper compounds involve redox reactions. The toxicity of copper comes from its ability to produce reactive oxygen species (ROS), displace
Resumen. El propósito de este estudio es el identificar la influencia del ligante aminoacidato en la actividad antiproliferativa a partir del análisis de una serie de compuestos con variaciones en la cadena lateral del aminoácido. Los resultados muestran que la hidrofobicidad del ligante incrementa la incorporación celular de $\mathrm{Cu}$ (II); sin embargo, no se ha encontrado una correlación entre la concentración intracelular de cobre con la actividad biológica. Los sustituyentes en los ligantes diimina cuentan con la mayor participación en el control de la actividad biológica. También se informan dos estructuras cristalinas de los compuestos 2 (Cas IIala) y 4 (Cas IInva).

Palabras clave: Cobre, chelate mezclado, aminoácidos, efecto ligante, componentes inorgánicos anticáncer, citotoxicidad, distribución intracelular.

other metal ions, peroxidize lipids and directly cleave DNA and RNA [18-23].

All these properties were taken into account in the design of copper (II) coordination compounds recorded and patented [24-26] under the name Casiopeínas ${ }^{\circledR}$ with general formulae $[\mathrm{Cu}(\mathrm{N}-\mathrm{N})(\mathrm{N}-\mathrm{O})] \mathrm{NO}_{3}$ and $[\mathrm{Cu}(\mathrm{N}-\mathrm{N})(\mathrm{O}-\mathrm{O})] \mathrm{NO}_{3}$; where the primary ligand $\mathrm{N}-\mathrm{N}=$ non substituted and substituted 2,2'-bipyridine (bipy) or 1,10-phenanthroline (phen); and the secondary ligand $\mathrm{N}-\mathrm{O}=\alpha$-aminoacidate or a peptide and $\mathrm{O}-\mathrm{O}=$ acetylacetonate (acac) or salicylaldehydate.

Two compounds of this family [Cu(4,4'-dimethyl-2,2'bipyridine)(acac) $] \mathrm{NO}_{3}$ (Casiopeína III-ia) and $[\mathrm{Cu}(4,7$-dimethyl-1,10-phenanthroline)(glycinate) $\mathrm{NO}_{3}$ (Casiopeína II-gly) have been evaluated in vitro and in vivo showing cytotoxic [27-29], genotoxic [27] and antineoplastic [30, 31] activity. The action mechanism is still not completely elucidated. However, there is evidence that supports the idea that these compounds are able to inhibit cell proliferation and produce cell dose-dependent death by apoptosis through mechanisms dependent and independent of caspase activation [31,32]. The apoptosis observed might be the result of several processes like generation of reactive oxygen species (ROS) [27, 33, 34] or mitochondrial toxicity [31,35, 36], which may act alone or in concomitance to produce cell death. In presence of reducing agents the cell growth inhibition [21, 24], and degradation of DNA [20, 21, 
25] are potentiated, simultaneously with ROS increment, which suggest that DNA oxidation in cells may also be involved in cell death. Besides, it is possible that these compounds interact with DNA by intercalation due to the planar moiety corresponding to the diimine or the acetylacetonate ligand [34, 37-39].

In a QSAR study [40], the antiproliferative activity on HeLa, SiHa, HCT-15 and MCF-7 cells for compounds with general formula $[\mathrm{Cu}(\mathrm{N}-\mathrm{N})(\mathrm{acac})] \mathrm{NO}_{3}$ and $[\mathrm{Cu}(\mathrm{N}-\mathrm{N})($ glycinato $)] \mathrm{NO}_{3}$ was analyzed. According with QSAR studies the presence of the central fused aromatic ring in the phen containing complexes is necessary to preserve the antiproliferative activity. The $\mathrm{IC}_{50}$ has a strong relationship with the half-wave potential $\left(\mathrm{E}_{1 / 2}\right)$ of the copper (II) center; being the most active those complexes which are weaker oxidants. A change in the secondary ligand from acac to glycinato has less influence on the biological activity when compared to the changes on the diimine ligand. It has been proposed that the role of the secondary ligand on antiproliferative activity is to assist the transport of the copper coordination compound across membranes due to an increment in hydrophobicity, acting as carriers in the uptake of copper (II). It is also possible that the modification of hydrophobic properties become more important by influencing directly the antiproliferative activity on a whole organism, where this property plays a major role in drug transport to the site of action. However, the exact contribution of the secondary ligand to the activity remained to be fully understood.

With the aim of understanding the role played by the secondary ligand on the biological activity shown by these coordination compounds, 13 copper (II) compounds with general formula $[\mathrm{Cu}(4,7$-dimethyl-1,10-phenanthroline $)(\alpha-$ aminoacidato) $] \mathrm{NO}_{3}$ were synthesized, characterized and their antiproliferative activity was evaluated in three human tumour cell lines HeLa, HCT-15 and SKL-U. The structural variants in these complexes are only in the $\alpha$-aminoacidato side-chain (Fig. 1).

\section{Results and Discussion}

For analysis purposes, complexes are classified in two groups: group 1, aliphatic aminoacids (compounds 1-8); and group 2, aminoacids with aromatic or heterocyclic rings (compounds 913). In the first group the hydrophobicity is enhanced with the increment of carbon chain length which allows analysing the effect of this property on the antiproliferative activity. In the second group, the structures are more varied and the electronic, steric and hydrophobic properties are modified simultaneously; however, they all share certain structural restrictions due to aromatic or heterocyclic rings. Results show that the changes performed on aminoacidate ligand have less influence on the activity than those performed on diimine. Complexes with aromatic or heterocyclic rings are more active than those with aliphatic aminoacids. The hydrophobicity enhancement due to the increase of carbons in the side-chain of aliphatic aminoacidates increases the cellular copper intake; however, the correlation with $\log \mathrm{P}$ or $\mathrm{IC}_{50}$ is not direct.

The complexes synthesized exhibit IR absorption bands typical for coordinated ligands, 4,7-dimethyl-1,10-phenanthroline absorption bands are present in 1630, 1520, 1435, 885 and $725 \mathrm{~cm}^{-1}$. Aminoacidate ligands shown absorption bands around $3400-3200,1600-1570$ and $660-650 \mathrm{~cm}^{-1}$ for amines and 1640-1600, 1400-1380, 800-730, 565-540, 490-460 $\mathrm{cm}^{-1}$ for caboxylate moiety. $\mathrm{NO}_{3}{ }^{-}$as counter ion $\left(\approx 1384 \mathrm{~cm}^{-1}\right)$ and water molecules.

Compounds with aliphatic aminoacidato showed a better water solubility than the corresponding aromatic with exception of the aminobutiric acid derivative. All compounds showed an effective magnetic moment (1.68-2.05 BM) that agrees with paramagnetic species with one unpaired electron. The conductimetric measurements of ternary compounds shown a 1:1 type electrolyte (in water for compounds 1-8 and in methanol for compounds 9-12) confirming the +2 oxidation state of copper ion.

$\mathrm{X}$-ray structure determination for ternary copper (II) complexes previously reported by our group [41-50], $\left[\mathrm{Cu}\left(\mathrm{H}_{2} \mathrm{O}\right)(1,10-\right.$ phenanthroline)(L-serinato) $] \mathrm{NO}_{3}, \quad\left[\mathrm{Cu}\left(\mathrm{H}_{2} \mathrm{O}\right)(3,4,7,8\right.$-tetramethyl-1,10-phenanthroline)(L-glycinato) $\mathrm{NO}_{3}$ or $\left[\mathrm{Cu}\left(\mathrm{H}_{2} \mathrm{O}\right)(4,7\right.$-diphenyl-1, 10 - phenanthroline)( $\mathrm{L}$ alaninato) $] \mathrm{NO}_{3}$, present a slightly distorted square pyramid coordination environment around the copper ion with a water molecule occupying the apical position. Figure 2 shows the molecular structure of compounds $\mathbf{2}$ and $\mathbf{4}$. The molecular ge-

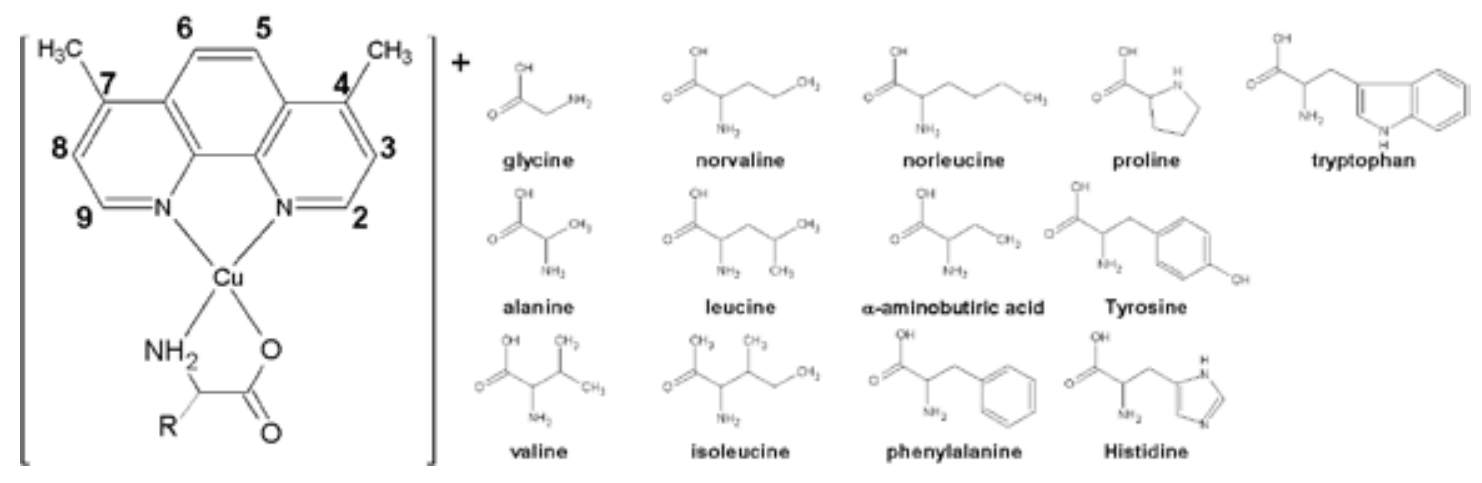

Fig. 1. General structure for $[\mathrm{Cu}(4,7 \text {-dimethyl-1,10-phenanthroline })(\alpha \text {-aminoacidato })]^{+}$and structures of amino acids employed as secondary ligand. 
Table 1. Crystallographic data for compound 2 and 4.

\begin{tabular}{lll}
\hline Compound & $\mathbf{2}$ & $\mathbf{4}$ \\
\hline Formula & $\mathrm{C}_{17} \mathrm{H}_{18} \mathrm{CuF}_{6} \mathrm{~N}_{3} \mathrm{O}_{2} \mathrm{P}$ & $\mathrm{C}_{19} \mathrm{H}_{24} \mathrm{CuF}_{6} \mathrm{~N}_{3} \mathrm{O}_{3} \mathrm{P}$ \\
Formula weight & 504.85 & 550.92 \\
Temperature & $298(2) \mathrm{K}$ & $293 \mathrm{~K}$ \\
Crystal dimensions & $0.31 \times 0.08 \times 0.03 \mathrm{~mm}$ & $0.70 \times 0.27 \times 0.06 \mathrm{~mm}$ \\
Wavelength & $0.71073 \AA$ & $0.71073 \AA$ \\
Crystal system & Monoclinic & Monoclinic \\
Space group & $\mathrm{P} 2{ }_{1}$ & $\mathrm{P} 12_{1} / \mathrm{m} 1$ \\
Lattice parameters & $\boldsymbol{a}=11.2063(19) \AA$ & \\
$\boldsymbol{b}=7.0437(14) \AA$ & & \\
$\boldsymbol{c}=12.4718(11) \AA$ & & \\
$\beta=99.431(13)^{\circ}$ & $\mathrm{a}=11.8295(7) \AA$ & \\
$\mathrm{b}=7.0008(5) \AA$ & & \\
$\mathrm{c}=13.4027(9) \AA$ & & \\
$\beta=101.119(6)^{\circ}$ & & \\
Volume & & \\
$\mathrm{Z}$ & & \\
Final R indices[I $>2 \sigma(\mathrm{I})]$ & 0.059 & 0.059 \\
$\mathrm{R}$ indices (all data) & 0.158 & \\
\hline
\end{tabular}

ometry of the cationic compound $\mathbf{2}$ (Cas IIala) is also a five coordinated $\mathrm{Cu}$ (II) centre but in an extremely distorted squarepyramidal geometry because the apical position is occupied by an oxygen atom of the carboxylic group of the neighboring coordination compound. Compound 4 (Cas IInval) presents the slightly distorted square base pyramid with the water molecule occupying the apical position already found in these copper (II) coordination compounds. Table 1 summarizes the crystallographic data for compounds 2 and 4. Selected bond lengths and angles are shown in Table 2.

The coordination of the oxygen in the carboxylate moiety to the copper ion in compound $\mathbf{2}$ promotes a zigzag conformation of the molecules in a $1 \mathrm{D}$ chain arrangement as shown in Figure 3. Hydrogen bond interactions also help in the stabilization of the crystal arrangement; a $\mathrm{PF}_{6}{ }^{-}$molecule interacts with hydrogen atoms of four different coordination compound

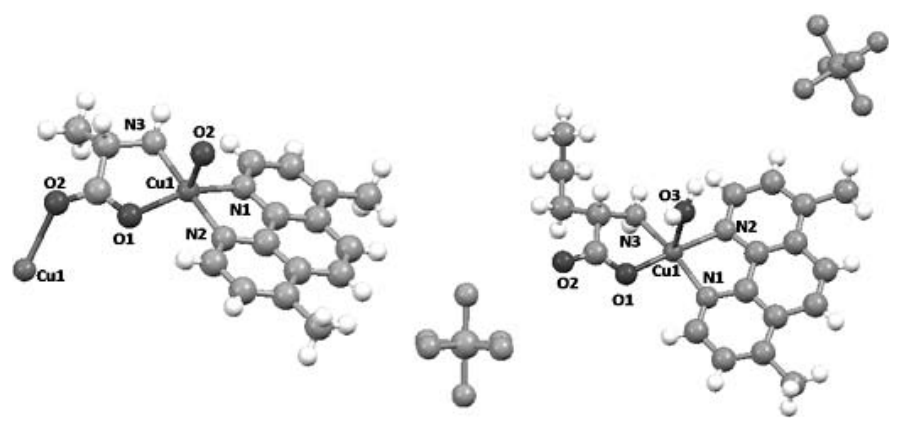

Fig. 2. Molecular structure of compound $2[\mathrm{Cu}(4,7-$ dimethyl-1,10-phe nanthroline)(alaninato) $] \mathrm{PF}_{6}$ (CasIIala) (left) and compound $4[\mathrm{Cu}(4,7-$ dimethyl-1,10-phenanthroline)(norvalinato) $] \mathrm{PF}_{6}$ (CasIInval) (right). molecules belonging of two 1D chains, with hydrogen bond

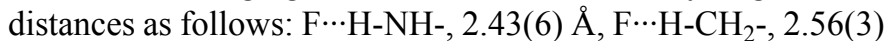
$\AA$, F $\cdots \mathrm{H}-\mathrm{C}($ aromatic), 2.54(7) $\AA$ and $\mathrm{F} \cdots \mathrm{H}-\mathrm{C}($ aromatic), 2.65(4) $\AA$. Also can be observed an intra-chain hydrogen bond formed between carboxylate oxygen of one molecule and the methylene hydrogen of the next compound. In compound 4, the coordinated water molecule and the non-coordinated oxygen of the carboxylate are involved in a hydrogen bond, the former

Table 2. Selected bond lengths $(\AA)$ and angles $\left(^{\circ}\right)$ of compound 2 and 7.

\begin{tabular}{llll}
\hline \multicolumn{2}{c}{ Compound 2 } & \multicolumn{2}{c}{ Compound 7} \\
\hline $\mathrm{Cu} 1-\mathrm{O} 1$ & $1.961(4) \AA$ & $\mathrm{Cu} 1-\mathrm{O} 1$ & $1.938(4)$ \\
$\mathrm{Cu} 1-\mathrm{N} 3$ & $1.969(5) \AA$ & $\mathrm{Cu} 1-\mathrm{N} 3$ & $1.977(5)$ \\
$\mathrm{Cu} 1-\mathrm{N} 2$ & $1.994(4) \AA$ & $\mathrm{Cu} 1-\mathrm{N} 1$ & $2.004(3)$ \\
$\mathrm{Cu} 1-\mathrm{N} 1$ & $2.044(4) \AA$ & $\mathrm{Cu} 1-\mathrm{N} 2$ & $2.016(4)$ \\
$\mathrm{Cu} 1-\mathrm{O} 2{ }^{\mathrm{i}}$ & $2^{2.268(5)} \AA$ & $\mathrm{Cu} 1-\mathrm{O} 3$ & $2.356(5)$ \\
$\mathrm{O} 1-\mathrm{Cu} 1-\mathrm{N} 3$ & $84.4(2)^{\circ}$ & $\mathrm{O} 1-\mathrm{Cu} 1-\mathrm{N} 3$ & $83.68(18)$ \\
$\mathrm{O} 1-\mathrm{Cu} 1-\mathrm{N} 2$ & $96.39(18)^{\circ}$ & $\mathrm{O} 1-\mathrm{Cu} 1-\mathrm{N} 1$ & $93.38(16)$ \\
$\mathrm{N} 3-\mathrm{Cu} 1-\mathrm{N} 2$ & $179.0(3)^{\circ}$ & $\mathrm{N} 3-\mathrm{Cu} 1-\mathrm{N} 1$ & $166.6(3)$ \\
$\mathrm{O} 1-\mathrm{Cu} 1-\mathrm{N} 1$ & $151.5(3)$ & $\mathrm{O} 1-\mathrm{Cu} 1-\mathrm{N} 2$ & $172.84(18)$ \\
$\mathrm{N} 3-\mathrm{Cu} 1-\mathrm{N} 1$ & $97.9(2)^{\circ}$ & $\mathrm{N} 3-\mathrm{Cu} 1-\mathrm{N} 2$ & $102.03(19)$ \\
$\mathrm{N} 2-\mathrm{Cu} 1-\mathrm{N} 1$ & $81.71(16)^{\circ}$ & $\mathrm{N} 1-\mathrm{Cu} 1-\mathrm{N} 2$ & $82.04(16)$ \\
$\mathrm{O} 1-\mathrm{Cu} 1-\mathrm{O} 2$ & $100.03(19)^{\circ}$ & $\mathrm{O} 1-\mathrm{Cu} 1-\mathrm{O} 3$ & $91.15(17)$ \\
$\mathrm{N} 3-\mathrm{Cu} 1-\mathrm{O} 2$ & $96.2(3)^{\circ}$ & $\mathrm{N} 3-\mathrm{Cu} 1-\mathrm{O} 3$ & $95.7(2)$ \\
$\mathrm{N} 2-\mathrm{Cu} 1-\mathrm{O} 2$ & $83.0(2)^{\circ}$ & $\mathrm{N} 1-\mathrm{Cu} 1-\mathrm{O} 3$ & $97.4(2)$ \\
$\mathrm{N} 1-\mathrm{Cu} 1-\mathrm{O} 2$ & $107.9{ }^{\circ}$ & $\mathrm{N} 2-\mathrm{Cu} 1-\mathrm{O} 3$ & $84.0(2)$ \\
\hline
\end{tabular}



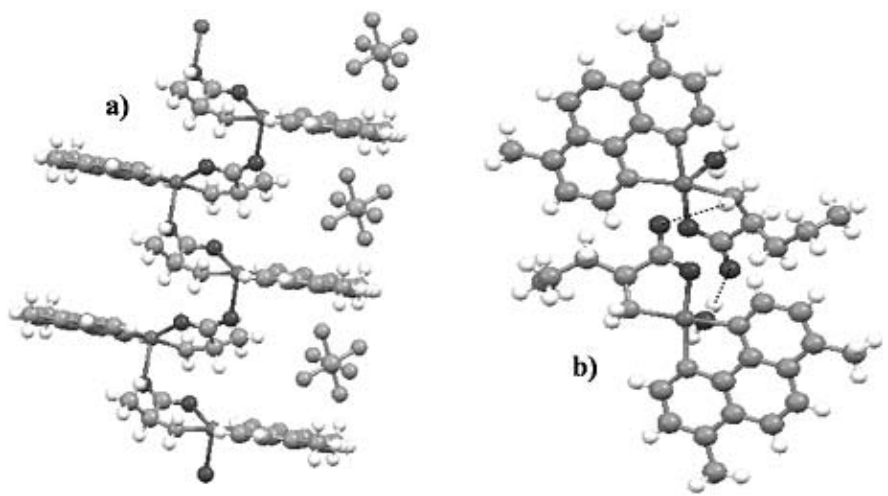

Fig. 3. Zigzag conformation adopted by compound $\mathbf{2}$ due the coordination of carboxylate to the next copper (II) centre (a). Hydrogen bonds presented in the crystal structure of compound 4 (b). Hydrogen atoms are not shown for clarity.

interacts with the non-coordinated carboxylate oxygen of the nearby coordination compound $(\mathrm{O} \cdots \mathrm{H}-\mathrm{OH}, 1.99(8) \AA)$, meanwhile, the latter interacts with the hydrogens of the amino group of the same neighbor $(\mathrm{O} \cdots \mathrm{H}-\mathrm{NH}-, 2.46(7) \AA)$ (Fig. 3).

The antiproliferative effect of the compounds was determined as $\mathrm{IC}_{50}$ value on human tumour cell lines HeLa, HCT-15 and SKL-U by means of colorimetric microculture assay (sulforhodamine B assay) and reported in Table 3 as micromolar doses. Almost all compounds show lower doses than $10 \mu \mathrm{M}$ on the three tumour cell lines with exception of compounds 2 with $13.96 \mu \mathrm{M}$ in HCT-15 and 6 with $10.10 \mu \mathrm{M}$ in SKL-U cell line.

In almost all cases, lower values than those exhibited by cisplatin in the different cell lines were found. Figure 4 shows the greater susceptibility of HeLa cells to the tested compounds, the $\mathrm{IC}_{50}$ values in this tumour cell line range from $1.3 \mu \mathrm{M}$, for compound $\mathbf{1}$, to $3.0 \mu \mathrm{M}$, for compound $\mathbf{1 1}$. This narrow interval

Table 3. Antiproliferative activity $\left(\mathrm{IC}_{50}, \mu \mathrm{M}\right)$ of Casiopeínas on the tumor human cell lines HeLa, HCT-15 and SKL-U

\begin{tabular}{clccc}
\hline Compound & Secondary ligand & HeLa & HCT-15 & SKL-U \\
\hline 1 & Glycinate & 1.33 & 3.7 & 4.97 \\
2 & Alaninate & 1.90 & 13.96 & 9.56 \\
3 & Valinate & 1.50 & 4.59 & 8.98 \\
4 & norvalinate & 1.74 & - & - \\
5 & Leucinate & 1.52 & 6.51 & 8.51 \\
6 & isoleucinate & 1.64 & 7.99 & 10.10 \\
7 & norleucinate & 1.33 & 3.68 & 9.09 \\
8 & a-aminobutirate & 1.72 & 6.93 & 8.4 \\
9 & phenylalaninate & 2.04 & 2.74 & 4.49 \\
10 & Prolinate & 1.93 & 1.72 & 3.73 \\
11 & Tyrosinate & 3.03 & 3.39 & 2.70 \\
12 & Histidinate & 1.78 & 2.60 & 3.20 \\
13 & tryptophanate & 2.30 & 4.82 & 5.41 \\
Cisplatin & & 4.90 & 9.91 & 9.56 \\
\hline
\end{tabular}

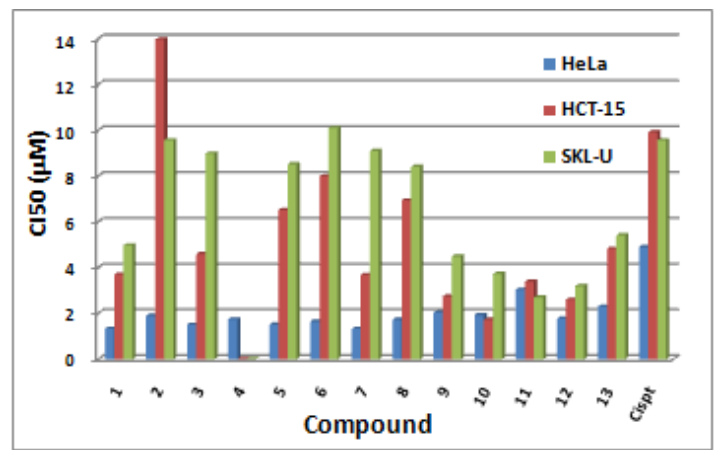

Fig. 4. Antiproliferative activity on HeLa, HCT-15 and SKL-U for compounds 1-13 and Cisplatin reported as $\mathrm{IC}_{50} \mu \mathrm{M}$.

reflects a lack of sensitivity to structural changes in aminoacidato side-chain on HeLa cell line. The same trend has been observed before in previous works where different cell lines exhibit slight susceptibility differences to structural changes [40]. The group with heterocyclic aminoacidates (group 2) is slightly more active than its counterparts with aliphatic aminoacidates (group 1), this trend is more clear on HCT-15 and SKL-U where the differences between values, as mentioned before, are greater than on HeLa.

Regarding group 1 (compounds 1-8), the structural difference lies in the length of the carbon side-chain, which brings simultaneously differences on steric effects and hydrophobicity. The latter property is a determining factor for drug transport across membranes. Cellular copper intake is tightly regulated by specific membrane transporter Ctr1 [51-53]; however, the change in hydrophobicity might facilitate the non regulated transport across membranes causing copper overload and increasing, as consequence, the biological response.

In order to understand the influence of hydrophobicity on copper uptake, the intracellular copper quantification by atomic absortion spectroscopy on HeLa cultures treated with $200 \mu \mathrm{M}$ of complexes 1-8 by $15 \mathrm{~min}$ was performed. It is worthy to emphasize that the culture response to this concentration during 15 min exposure was evaluated before by Sulforhodamine B assay without changes on proliferation (data not shown). Results confirm that intracellular copper concentrations are increased in the cultures exposed to the complexes when compared with cultures exposed to $\mathrm{Cu}\left(\mathrm{NO}_{3}\right)_{2}$ (Fig. 5), leading to suggest that the presence of the ligands assist the copper uptake. The general trend indicates that the more hydrophobic the structure is, the more intracellular copper is found; however, the intracellular concentration does not strictly correlate with $\log \mathrm{P}$ and $\mathrm{IC}_{50}$ values.

The variations in the $\mathrm{IC}_{50}$ values are clearly related with structural changes, modifications on diimine ligand (primary ligand) promote greater changes in the in vitro antiproliferative activities than the modifications done in the aminoacidate side chain.

With the aim of confirming that modifications in the ligand produce minimal modifications in the antiproliferative activities of the $\mathrm{Cu}(\mathrm{II})$ coordination compounds, $\mathrm{IC}_{50}$ for groups 1 


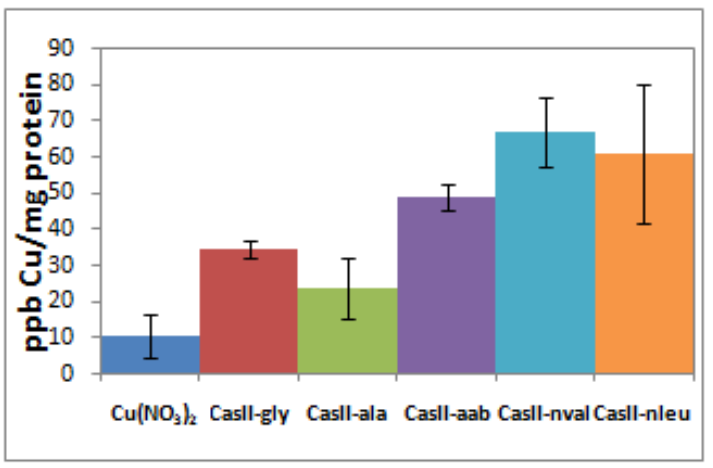

Fig. 5. Intracellular copper concentrations (ppb Cu/mg protein) quantified by atomic absortion spectroscopy on HeLa cultures exposed to $200 \mu \mathrm{M}$ of complexes 1-8 by 15 minutes. The compounds are placed from left to right in order of length of carbon side-chain. $\left({ }^{*} p=0.025\right.$; $* * p=0.001)$

and 2 were plotted together with $\mathrm{IC}_{50}$ previously reported for complexes $[\mathrm{Cu}(\mathrm{N}-\mathrm{N})($ glycinate $)] \mathrm{NO}_{3}$ on HeLa cell line [40], where the structural changes were performed only on diimina ligand (Fig. 6). Since previous QSAR studies revealed both, the strong relationship of the biologic activity with the electronic environment of the metal center and the influence of N-N ligand basicity on copper electronic properties, $\mathrm{pKa}$ for diimina ligand $\left(\mathrm{pKa}_{N-N}\right)$ was selected as $x$ axis to complete the comparisons. Figure 6 shows, as expected, that variations on diimine moiety have a stronger influence on antiproliferative activity, and are described adequately by pKa $(\mathrm{r}=-0.8548)$.

In this work we attempted to understand the influence of the secondary ligand in $\mathrm{Cu}$ (II) coordination compounds with general formula $[\mathrm{Cu}(4,7$-dimethyl-1,10-phen $)(\mathrm{N}-\mathrm{O})] \mathrm{NO}_{3}$ on the antiproliferative activity against human tumor cell lines HeLa, HCT-15 and SKL-U, employing a set of compounds with structural variations only on the side chain of aminoacidato. We found that the hydrophobicity of the ligands increases the cellular uptake of copper (II); however, the requirements of this property for in vitro activity are satisfied by all molecules and it is not the main limiting factor in the mode of action as it is demonstrated by the narrow interval of $\mathrm{IC}_{50}$ for this set of complexes, and confirmed by the lack of correlation of copper intracellular concentrations with in vitro activity. As reported before the substituents on diimine control the electronic environment around copper the atom [40] and this parameter is the dominant factor in the mode of action. The secondary ligand could have a key role in vivo where stability of ternary complexes and hydrophobicity are required to address the molecule to the final target.

\section{Experimental}

All chemicals and solvents were purchased from Aldrich Chemical Co. and GFS Chemicals Inc., and were used without further purification. Elemental analysis was done in a Fission Instruments Analyzer EA 1108, IR spectra were obtained employing

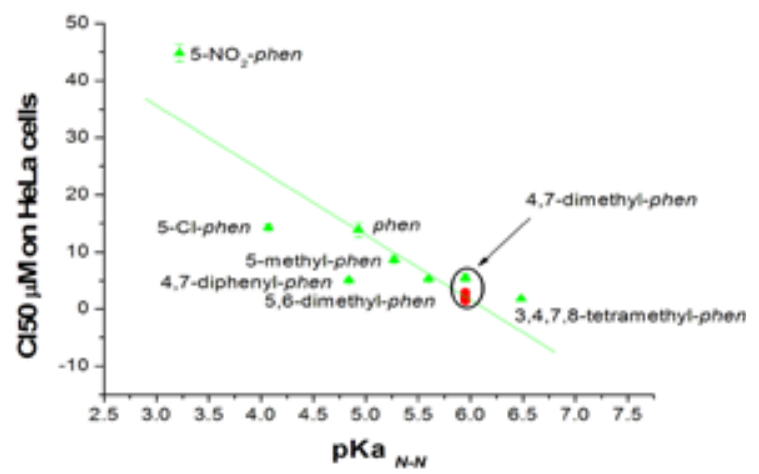

Fig. 6. Antiproliferative activity on HeLa for 2 sets of compounds Vs. pKa for diimine ligand $\left(\mathrm{pKa}_{N-N}\right) .[\mathrm{Cu}(N-N)$ (glycinato) $] \mathrm{NO}_{3}$, solid triangles; $\left[\mathrm{Cu}(4,7\right.$-dimethyl-phenanthroline)(aminoacidato) $] \mathrm{NO}_{3}$, solid circles.

a Nicolet Avatar 320 FT-IR, conductimetric and magnetic determinations were done in a Jenway 4330 Conductivity and $\mathrm{pH}$ meter and a Mkl magnetic balance from Sherwood Scientific respectively, UV-vis spectra were recorded in a Hewlett Packard 8452 diode array spectrophotometer. The UV-vis spectra and conductimetry were recorded in $\mathrm{MeOH}$ for some compounds (9-13) due to their low solubility in water.

Synthesis of $[\mathrm{Cu}(4,7$-dimethyl-1,10-phenanthroline $)(\alpha$ aminoacidato $\left.)\left(\mathrm{H}_{2} \mathrm{O}\right)\right] \mathrm{NO}_{3}$. All compounds were synthesized following the reported patents $[25,26]$.

Aqua (4,7-dimethyl-1,10-phenanthroline)(glycinato) copper(II) nitrate-hydrate (Casiopeína IIgly) (1). Yield 90\%. Elemental analysis data: calculated (\%) for $\mathrm{C}_{16} \mathrm{H}_{20} \mathrm{CuN}_{4} \mathrm{O}_{7}$ (443.9): C, 43.57; N, 12.52; H, 4.58. Found (\%): C, 43.29; $\mathrm{N}, 12.62 ; \mathrm{H}, 4.54$. IR (KBr, v/ $\left.\mathrm{cm}^{-1}\right): 3305,3253,2945,1600$, $1579,1430,1383\left(\mathrm{NO}_{3}^{-}\right), 871,726,637$. UV $\left(\mathrm{H}_{2} \mathrm{O}, \varepsilon / \mathrm{M}^{-1} \mathrm{~cm}^{-1}\right)$ $\mathrm{nm}: \lambda_{\max } 611$ (116). $\mu_{\mathrm{eff}}=1.78 \mathrm{BM} . \Lambda\left(\mathrm{H}_{2} \mathrm{O}\right)=102.05 \mathrm{mS}$.

(4,7-dimethyl-1,10-phenanthroline)(alaninato) copper(II) nitrate (Casiopeína IIala) (2). Yield 70\%. Elemental analysis data: calculated (\%) for $\mathrm{C}_{17} \mathrm{H}_{18} \mathrm{CuN}_{4} \mathrm{O}_{5}$ (421.9): $\mathrm{C}$, 48.24; N, 13.2; H, 4.28. Found (\%): C, 48.4; N, 13.28; H, 4.3. IR $\left(\mathrm{KBr}, \mathrm{v} / \mathrm{cm}^{-1}\right): 3430,2940,1656,1578,1427,1382\left(\mathrm{NO}_{3}{ }^{-}\right)$, $1157,932,871,726,637$. UV $\left(\mathrm{H}_{2} \mathrm{O}, \varepsilon / \mathrm{M}^{-1} \mathrm{~cm}^{-1}\right) \mathrm{nm}: \lambda_{\max } 596$ (120). $\mu_{\text {eff }}=1.895$ BM. $\Lambda\left(\mathrm{H}_{2} \mathrm{O}\right)=104.65 \mathrm{mS}$.

Aqua (4,7-dimethyl-1,10-phenanthroline)(valinato) copper(II) nitrate (Casiopeína IIval) (3). Yield 60\%. Elemental analysis data: calculated (\%) for $\mathrm{C}_{19} \mathrm{H}_{24} \mathrm{CuN}_{4} \mathrm{O}_{6}(467.95)$ : $\mathrm{C}$, 48.67; N, 11.98; H, 5.3. Found (\%): C, 48.77; N, 11.97; H, 5.17. IR (KBr, v/cm $\left.{ }^{-1}\right): 3305,3243,2961,1647,1578,1427,1385$ $\left(\mathrm{NO}_{3}^{-}\right), 1130,933,871,726,637$. UV $\left(\mathrm{H}_{2} \mathrm{O}, \varepsilon / \mathrm{M}^{-1} \mathrm{~cm}^{-1}\right) \mathrm{nm}$ : $\lambda_{\max }=609$ (100). $\mu_{\text {eff }}=1.814$ BM. $\Lambda\left(\mathrm{H}_{2} \mathrm{O}\right)=100.49 \mathrm{mS}$.

Aqua (4,7-dimethyl-1,10-phenanthroline)(norvalinat o) copper(II) nitrate (Casiopeína IInval) (4). Yield $10 \%$. Elemental analysis data: calculated (\%) for $\mathrm{C}_{19} \mathrm{H}_{26} \mathrm{CuN}_{4} \mathrm{O}_{7}$ (485.97): C, 46.95; N, 11.52; H, 5.39. Found (\%): C, 47.35; $\mathrm{N}, 11.81 ; \mathrm{H}, 5.38$. IR (KBr, v/ $\left.\mathrm{cm}^{-1}\right): 3437,3244,2960,1624$, 1580, 1426, $1384\left(\mathrm{NO}_{3}^{-}\right), 1130,932,871,726,690 . \mathrm{UV}\left(\mathrm{H}_{2} \mathrm{O}\right.$, $\left.\varepsilon / \mathrm{M}^{-1} \mathrm{~cm}^{-1}\right) \mathrm{nm}: \lambda_{\max } 602(57) . \mu_{\text {eff }}=1.754$ BM. $\Lambda(\mathrm{MeOH})$ $=91.3 \mathrm{mS}$. 
Aqua (4,7-dimethyl-1,10-phenanthroline)(leucinato) copper(II) nitrate (Casiopeína IIleu) (5). Yield 50\%. Elemental analysis data: calculated (\%) for $\mathrm{C}_{20} \mathrm{H}_{26} \mathrm{CuN}_{4} \mathrm{O}_{6}$ (481.98): C, 49.63; N, 11.52; H, 5.44. Found (\%): C, 49.84; N, 11.62; H, 5.44. IR (KBr, v/cm ${ }^{-1}$ ): 3440, 3261, 2954, 1649, 1580, 1425 , $1383\left(\mathrm{NO}_{3}{ }^{-}\right), 1118,931,871,726,637$. UV $\left(\mathrm{H}_{2} \mathrm{O}, \varepsilon / \mathrm{M}^{-1} \mathrm{~cm}^{-1}\right)$ $\mathrm{nm}: \lambda_{\max } 595(86) . \mu_{\mathrm{eff}}=1.771 \mathrm{BM} . \Lambda\left(\mathrm{H}_{2} \mathrm{O}\right)=100.10 \mathrm{mS}$.

Aqua (4,7-dimethyl-1,10-phenanthroline)(isoleucinato) copper(II) nitrate-dihydrate (Casiopeína IIile) (6). Yield $60 \%$. Elemental analysis data: calculated ( $\%)$ for $\mathrm{C}_{20} \mathrm{H}_{30} \mathrm{CuN}_{4} \mathrm{O}_{8}$ (517.98): C, 46.42; N, 10.58; H, 6.02. Found (\%): C, 46.37; N, 10.82; H, 5.84. IR (KBr, $\left.v / \mathrm{cm}^{-1}\right): 3463,2963,1615,1579$, 1427, $1384\left(\mathrm{NO}_{3}{ }^{-}\right), 1172,930,871,726,637 . \mathrm{UV}\left(\mathrm{H}_{2} \mathrm{O}, \varepsilon / \mathrm{M}^{-}\right.$ $\left.{ }^{1} \mathrm{~cm}^{-1}\right) \mathrm{nm}: \lambda_{\max } 605$ (76). $\mu_{\mathrm{eff}}=1.685$ BM. $\Lambda\left(\mathrm{H}_{2} \mathrm{O}\right)=98.25$ $\mathrm{mS}$.

Aqua(4,7-dimethyl-1,10-phenanthroline)(norleucinato) copper(II) nitrate·hydrate (Casiopeína IInleu). (7) Yield $65 \%$. Elemental analysis data: calculated ( $\%$ ) for $\mathrm{C}_{20} \mathrm{H}_{28} \mathrm{CuN}_{4} \mathrm{O}_{7}$ (499.98): C, 48.02; N, 11.44; H, 5.26. Found (\%): C, 48.04; N, 11.21; H, 5.64. IR (KBr, v/ $\left.\mathrm{cm}^{-1}\right)$ : 3313, 3243, 2954, 1657, $1579,1426,1384\left(\mathrm{NO}_{3}{ }^{-}\right), 1116,932,871,726,637 . \mathrm{UV}\left(\mathrm{H}_{2} \mathrm{O}\right.$, $\left.\varepsilon / \mathrm{M}^{-1} \mathrm{~cm}^{-1}\right) \mathrm{nm}: \lambda_{\max } 614(50) . \mu_{\mathrm{eff}}=1.692 \mathrm{BM} . \Lambda\left(\mathrm{H}_{2} \mathrm{O}\right)=$ $126.88 \mathrm{mS}$.

Aqua (4,7-dimethyl-1,10-phenanthroline)( $\alpha$-aminobutiric acid) copper(II) nitrate-dihydrate (Casiopeína IIaaba) (8). Yield 72\%. Elemental analysis data: calculated (\%) for $\mathrm{C}_{18} \mathrm{H}_{26} \mathrm{CuN}_{4} \mathrm{O}_{8}$ (489.93): C, 44.67; N, 12.19; H, 5.27. Found (\%): C, 44.12; N, 11.43; H, 5.53. IR $\left(\mathrm{KBr}, \mathrm{v} / \mathrm{cm}^{-1}\right): 3326$, 3222, 2962, 1627, 1580, 1423, $1383\left(\mathrm{NO}_{3}{ }^{-}\right), 1160,932,871$, 726,637 . UV $\left(\mathrm{H}_{2} \mathrm{O}, \varepsilon / \mathrm{M}^{-1} \mathrm{~cm}^{-1}\right) \mathrm{nm}: \lambda_{\max } 626(50) . \mu_{\mathrm{eff}}=2.05$ BM. $\Lambda\left(\mathrm{H}_{2} \mathrm{O}\right)=121.55 \mathrm{mS}$.

Aqua (4,7-dimethyl-1,10-phenanthroline)(phenylalanin ato) copper(II) nitrate·hydrate (Casiopeína IIphe) (9). Yield $69 \%$. Elemental analysis data: calculated ( $\%$ ) for $\mathrm{C}_{23} \mathrm{H}_{27} \mathrm{CuN}_{4} \mathrm{O}_{7}$ (535.04): C, 51.37; N, 10.47; H, 5.04. Found (\%): C, 51.67; N, 10.49; H, 5.09. IR ( $\left.\mathrm{KBr}, v / \mathrm{cm}^{-1}\right): 3423,2945,1622,1579$, 1525, 1427, $1383\left(\mathrm{NO}_{3}^{-}\right), 1137,858,726,637 . \mathrm{UV}(\mathrm{MeOH}$, $\left.\varepsilon / \mathrm{M}^{-1} \mathrm{~cm}^{-1}\right) \mathrm{nm}: \lambda_{\max } 604(70) . \mu_{\mathrm{eff}}=1.72 \mathrm{BM} . \Lambda(\mathrm{MeOH})=$ $89.3 \mathrm{mS}$.

Aqua (4,7-dimethyl-1,10-phenanthroline)(prolinato) copper(II) nitrate-hydrate (Casiopeína IIpro) (10). Yield $63 \%$. Elemental analysis data: calculated (\%) for $\mathrm{C}_{19} \mathrm{H}_{22} \mathrm{CuN}_{4} \mathrm{O}_{6}$ (465.95): C, 48.83; N, 12.06; H, 4.86. Found (\%): C, 49.02; N, 12.04; H, 4.77. IR (KBr, v/cm $\left.{ }^{-1}\right): 3428,2945,1641,1578$, 1523, 1426, $1383\left(\mathrm{NO}_{3}^{-}\right), 1176,852,726,637$. UV (MeOH, $\left.\varepsilon / \mathrm{M}^{-1} \mathrm{~cm}^{-1}\right) \mathrm{nm}: \lambda_{\max } 598(60) . \mu_{\mathrm{eff}}=1.70 \mathrm{BM} . \Lambda(\mathrm{MeOH})=$ $90.2 \mathrm{mS}$.

(4,7-dimethyl-1,10-phenanthroline)(tyrosinato) copper(II) nitrate (Casiopeína IItyr) (11). Yield 60\%. Elemental analysis data: calculated (\%) for $\mathrm{C}_{23} \mathrm{H}_{22} \mathrm{CuN}_{4} \mathrm{O}_{6}$ (513.08): C, 53.74; N, 10.76; H, 4.47. Found (\%): C, 53.76; $\mathrm{N}, 10.9 ; \mathrm{H}, 4.31$. IR $\left(\mathrm{KBr}, \mathrm{v} / \mathrm{cm}^{-1}\right): 3303,2945,1660,1580$, 1525, 1426, $1384\left(\mathrm{NO}_{3}^{-}\right), 1173,864,726,637$. UV $(\mathrm{MeOH}$, $\left.\varepsilon / \mathrm{M}^{-1} \mathrm{~cm}^{-1}\right) \mathrm{nm}: \lambda_{\max } 602(80) . \mu_{\mathrm{eff}}=1.71 \mathrm{BM} . \Lambda(\mathrm{MeOH})=$ $80.2 \mathrm{mS}$.
Aqua (4,7-dimethyl-1,10-phenanthroline)(histidinato) copper(II) nitrate-hydrate (Casiopeína IIhis) (12). Yield $41 \%$. Elemental analysis data: calculated (\%) for $\mathrm{C}_{20} \mathrm{H}_{24} \mathrm{CuN}_{6} \mathrm{O}_{9}$ (523.10): C, 45.34; N, 16.24; H, 4.54. Found (\%): C, 45.84; N, 16.04; H, 4.64. IR ( $\left.\mathrm{KBr}, v / \mathrm{cm}^{-1}\right): 3385,2945,1629,1578$, $1525,1425,1383\left(\mathrm{NO}_{3}^{-}\right), 1172,856,726,637$. UV $(\mathrm{MeOH}$, $\left.\varepsilon / \mathrm{M}^{-1} \mathrm{~cm}^{-1}\right) \mathrm{nm}: \lambda_{\max } 662(95) . \mu_{\mathrm{eff}}=1.72 \mathrm{BM} . \Lambda(\mathrm{MeOH})=$ $92.6 \mathrm{mS}$.

(4,7-dimethyl-1,10-phenanthroline)(tryptophanato) copper(II) nitrate (Casiopeína IItrp) (13). Yield 55\%. Elemental analysis data: calculated (\%) for $\mathrm{C}_{25} \mathrm{H}_{23} \mathrm{CuN}_{5} \mathrm{O}_{5}$ (537.03): C, 55.91; N, 13.16; H, 5.05. Found (\%): C, 55.96; $\mathrm{N}, 13.06 ; \mathrm{H}, 4.32$. IR (KBr, $\left./ / \mathrm{cm}^{-1}\right): 3423,2945,1626,1580$, 1526, 1427, $1384\left(\mathrm{NO}_{3}^{-}\right), 1173,852,726,637$. UV $(\mathrm{MeOH}$, $\left.\varepsilon / \mathrm{M}^{-1} \mathrm{~cm}^{-1}\right) \mathrm{nm}: \lambda_{\max } 606(70) . \mu_{\mathrm{eff}}=1.72 \mathrm{BM} . \Lambda(\mathrm{MeOH})=$ $91.8 \mathrm{mS}$.

Tumor cell lines. HeLa (Cervix adenocarcinoma), HCT15 (Colorectal adenocarcinoma) and SKL-U (Lung adenocarcinoma) cell lines were purchased from the American Type Culture Collection (ATCC) and propagated in Dulbecco's Modified Eagle Medium (D-MEM, Gibco Invitrogen Corporation) supplemented with $10 \%$ fetal bovine serum (FBS, Gibco Invitrogen Corporation).

Cell growth inhibition. Details of measuring cell growth inhibition are described elsewhere [54, 55]. Briefly, $2 \times 10^{4}$ cells/well were plated in 96-well microplate with Dulbecco's Modified Eagle Medium (D-MEM) supplemented with 10\% fetal bovine serum (FBS), and allowed to attach by incubating at $37{ }^{\circ} \mathrm{C}$ and $5 \% \mathrm{CO}_{2}$ for $24 \mathrm{~h}$. At the end of incubation timing, the medium was aspired and cells were exposed to drugs in six different concentrations $(0.1,0.3,1,3,10$ and $30 \mu \mathrm{g} / \mathrm{ml})$ for $24 \mathrm{~h}$ in the conditions mentioned above. Cisplatin (cisPt) was employed as control drug. Cell growth was determined according to the Sulforhodamine B assay [54, 55]. Absorbance was measured at $564 \mathrm{~nm}$ in a BIO-RAD 550 Microplate reader and $\%$ cell growth by each concentration of drug was calculated as: $\%$ growth $=100 *[\mathrm{~T} / \mathrm{C}]$; where $\mathrm{T}$ is the absorbance of treated wells and $\mathrm{C}$ is the absorbance of untreated wells. The $50 \%$ growth inhibition $\left(\mathrm{IC}_{50}\right)$ was calculated by Probit survival analysis in StatPlus ${ }^{\circledR} 2005$ [56]. Reported $\mathrm{IC}_{50}$ values are the average of at least three independent experiments.

Intracellular Copper quantification, $2 \times 10^{6}$ cells/well were cultured in a 12-well microplate with Dulbecco's Modified Eagle Medium (D-MEM) supplemented with 10\% fetal bovine serum (FBS), and allowed to attach by incubating at $37{ }^{\circ} \mathrm{C}$ and $5 \% \mathrm{CO}_{2}$ for $24 \mathrm{~h}$. At the end of incubation time, the medium was aspired and cells were exposed to $200 \mu \mathrm{M}$ of compounds 1-8 for $10 \mathrm{~min}$ in the conditions mentioned above. After exposition time, cells were washed three times with cold PBS pH 7.4 and recovered with lysis buffer $\mathrm{pH} 7.4(\mathrm{NaCl}$ $150 \mathrm{mM}$, EDTA 1mM, SDS 0.1\%, Triton X-100 1\%, Tris- $\mathrm{HCl}$ $50 \mathrm{mM}$, PMSF 1mM). Two aliquots were separated of each sample in order to determine copper concentration and total protein concentration; the former was determined with Graphite Furnace Atomic Absorption Spectrophotometry (Varian Spectr AA 220-Graphite Furnace GTA 110). Total protein was deter- 
mined with DC BioRad's protein kit with a HP 8452A diode array spectrophotometer.

Single-crystal X-ray diffraction. Diffraction data for the complex was collected at $293 \mathrm{~K}$ on a Brucker $6000 \mathrm{CCD}$, using a monochromated Mo K $\alpha$ radiation $(\lambda=0.71073 \AA)$. The structure was solved by direct methods using SHELXS$97-2$, least-squares refinement based on $\mathrm{F}^{2}$ was carried out by full-matrix method [57]. All non-hydrogen atoms were refined with anisotropic thermal parameters. The hydrogen atoms for all the reported structures were located in the difference map and included in the refinement with an isotropic fixed thermal parameter using a "riding" model. Neutral atom scattering factors and anomalous dispersion corrections were obtained from the International Tables for Crystallography vol. A [58]. Unit cell parameters along with data collection and refinement details for these complexes are listed in Table 1. All molecular structure drawings were generated using the WINGX suite of crystallographic programs for Windows [59].

\section{Acknowledgments}

To CONACyT scholarship (SDM), SNI (JCGR), PAPIIT (MAMH) and F-634-3 (JFG). CONACyT-Salud 87806 and PAPIIT IN227110.

\section{Supporting Information Available}

The crystallographic data can be obtained free of charge via www.ccdc.cam.ac.uk/data_request/cif, or by emailing data_request@ccdc.cam.ac.uk, or by contacting The Cambridge Crystallographic Data Centre, 12, Union Road, Cambridge CB2 1EZ, UK; fax +44 1223336033 . CCDC 826177,826178 contains the supplementary crystallographic data for compounds $\mathbf{4}$ and $\mathbf{2}$, respectively.

\section{References}

1. Hambley, T. W. Science 2007, 318, 1392-1393.

2. Zhang, C. X.; Lippard, S. J. Curr. Opin. Chem. Biol. 2003, 7, 481-489.

3. van Rijt, S. H.; Sadler, P. J. Drug Discov. Today 2009, 14, 10891097.

4. Mejía-Vázquez, M. d. C.; Navarro, S. New Approaches in the Treatment of Cancer, Cancer Etiology, Diagnosis and Treatments Nova Sciences, New York, Chapter 10, 2010.

5. Alama, A; Tasso, B; Novelli, F. ; Sparatore, F. Drug Discov. Today 2009, 14, 500-508.

6. Kostova, I. Anticancer Agents Med. Chem. 2009 , 9, 827-842.

7. Messori, L.; Marcon, G.; Orioli, P. Bioinorg. Chem. Appl. 2003, 177-187.

8. Amin, A.; Buratovich, M. A. Mini Rev. Med. Chem. 2009, 9, 14891503.

9. Gao, E.; Liu, C.; Zhu, M.; Lin, H.; Wu, Q.; Liu, L. Anticancer Agents Med. Chem. 2009, 9, 356-368.

10. Chifotides, H. T.; Dunbar, K. R. Acc. Chem. Res. 2005, 38, 146156.
11. Hindo, S. S.; Frezza, M.; Tomco, D.; Heeg, M. J.; Hryhorczuk, L.; McGarvey, B. R.; Dou, Q. P.; Verani, C. N. Eur. J. Med. Chem. 2009, 44, 4353-4361.

12. Marzano, C.; Pellei, M; Tisato, F.; Santini, C. Anticancer Agents Med. Chem. 2009, 9, 185-211.

13. Ruiz-Azuara, L.; Bravo-Gomez, M. E. Curr. Med. Chem. 2010, 17, 3606-3615.

14. Tardito, S.; Marchio, L. Curr. Med. Chem. 2009, 16 (2009) 13251348.

15. Tisato, F.; Marzano, C.; Porchia, M.; Pellei, M.; Santini, C. Med. Res. Rev. 2010, 30, 708-749.

16. Fraústo da Silva, J. J. R.; Williams, R. J. P. The Biological Chemistry of the Elements - The Inorganic Chemistry of Life, Oxford University Press, Oxford, 1991.

17. Olivares, M.; Uauy, R. Am. J. Clin. Nutr. 1996, 63, 791S-796S.

18. Halliwell, B.; Gutteridge, J. M. Methods Enzymol. 1990, 186, 185.

19. Gaetke, L. M.; Chow, C. K. Toxicology 2003,189, 147-163.

20. Hill, R. Br. Vet. J. 1977, 133, 365-373.

21. Hill, R. Br. Vet. J. 1977, 133, 219-224.

22. Miller, D. M.; Buettner, G. R.; Aust, S. D. Free Radic. Biol. Med. 1990, 8, 95-108.

23. Sandstead, H. H. Am. J. Clin. Nutr. 1995, 61, 621S-624S.

24. Ruiz-Azuara, L. US Patent 1992 Re 35,458.

25. Ruiz-Azuara, L. US Patent 1992 RE 35,458, 1997.

26. Ruiz-Azuara, L. US Patent 1996 5, 576,326.

27. Alemón-Medina, R.; Breña-Valle, M.; Muñoz-Sánchez, J. L.; Gracia-Mora, M. I.; Ruiz-Azuara, L. Cancer Chemother. Pharmacol. 2007, 60, 219-228.

28. Gracia-Mora, I.; Ruiz-Ramírez, L.; Gómez-Ruiz, C.; Tinoco-Méndez, M.; Márquez-Quiñones, A.; Romero-De Lira, L.; MarínHernández, A.; Macías-Rosales, L.; Bravo-Gómez, M.E. MetalBased Drugs 2001, 8, 19-28.

29. Mejia, C.; Ruiz-Azuara, L. Pathol. Oncol. Res. 2008, 14, 467472.

30. Carvallo-Chaigneau, F.; Trejo-Solís, C.; Gómez-Ruiz, C.; Rodríguez-Aguilera, E.; Macías-Rosales, L.; Cortés-Barberena, E.; Cedillo-Peláez, C.; Gracia-Mora, I.; Ruiz-Azuara, L. ; MadridMarina, V.; Constantino-Casas, F. Biometals 2008, 21, 17-28.

31. Trejo-Solís, C.; Palencia, G.; Zuniga, S.; Rodriguez-Ropon, A.; Osorio-Rico, L.; Luvia, S. T.; Gracia-Mora, I.; Márquez-Rosado, L.; Sánchez, A.; Moreno-García, M. E.; Cruz, A.; Bravo-Gómez, M. E.; Ruiz-Ramírez, L.; Rodríguez-Enríquez, S.; Sotelo, J. Neoplasia 2005, 7, 563-574.

32. De Vizcaya-Ruiz, A.; Rivero-Muller, A.; Ruiz-Ramirez, L.; Kass, G. E.; Kelland, L. R.; Orr, R. M.; Dobrota, M. Toxicol. In Vitro 2000, 14, 1-5.

33. Alemón-Medina, R.; Muñoz-Sánchez, J. L.; Ruiz-Azuara, L.; Gracia-Mora, I. Toxicol. In Vitro 2008, 22, 710-715.

34. Rivero-Muller, A.; De Vizcaya-Ruiz, A.; Plant, N.; Ruiz, L.; Dobrota, M. Chem. Biol. Interact. 2007, 165, 189-199.

35. Hernández-Esquivel, L.; Marín-Hernández, A.; Pavón, N.; Carvajal, K.; Moreno-Sánchez, R. Toxicol. Appl. Pharmacol. 2006, 212, 79-88.

36. Marín-Hernández, A. Gracia-Mora, I. Ruiz-Ramírez, L. MorenoSánchez, R. Biochem. Pharmacol. 2003, 65, 1979-1989.

37. Ruili Huang, A. W.; Covell, D. G. Biochem. Pharmacol. 2005, 69, 1009-1039.

38. Sigman, D. S.; Mazumder, A.; Perrin, D. M. Chem. Rev. 1993, 93, 2295-2316.

39. Chikira, M.; Tomizawa, Y.; Fukita, D.; Sugizaki, T.; Sugawara, N.; Yamazaki, T.; Sasano, A.; Shindo, H.; Palaniandavar, M.; Antholine, W. E. J. Inorg. Biochem. 2002, 89, 163-173.

40. Bravo-Gómez, M. E.; García-Ramos, J. C.; Gracia-Mora, I.; RuizAzuara, L. J. Inorg. Biochem. 2009, 103, 299-309.

41. Tovar-Tovar, A.; Ruiz-Ramírez, L.; Campero, A.; Romerosa, A.; Moreno-Esparza, R.; Rosales-Hoz, M. J. J. Inorg. Biochem. 2004, 98, 1045-1053. 
42. Solans, X.; Ruiz-Ramírez, L.; Gasque, L.; Briansó, J. L. Acta Cryst. C 1987, 43, 428-430.

43. Solans, X.; Ruiz-Ramírez, L.; Martínez, A.; Gasque, L.; Briansó, J. L. Acta Cryst. C 1988, 44, 628-631.

44. Solans, X.; Ruiz-Ramírez, L.; Martínez, A.; Gasque, Moreno-Esparza, R. Acta Cryst. C 1992, 48, 1785-1788

45. Solans, X.; Ruiz-Ramírez, L.; Martínez, A.; Gasque, Moreno-Esparza, R. Acta Cryst C 1993, 49, 890-893.

46. Moreno-Esparza, R.; Molins, E.; Briansó-Penalva, J.L.; RuizRamírez, L.; Redón, R. Acta Cryst C 1995, 51, 1505-1508.

47. Gasque, L.; Moreno-Esparza, R.; Ruiz-Ramírez, L.; Medina-Dickinson, G. Acta Cryst C 1999, 55, 1065-1067.

48. Gasque, L.; Moreno-Esparza, R.; Ruiz-Ramírez, L.; Medina-Dickinson, G. Acta Cryst C 1999, 55, 1063-1065.

49. Alvarez-Larena, A.; Briansó-Penalva, J. L.; Piniella, J. F.; Moreno-Esparza, R.; Ruiz-Ramírez, L.; Ferrer-Sueta, G. Acta Cryst. C 1995, 51, 852-854.

50. Paulovicova, A; El-Ayaan, U.; Fukuda, Y. Inorg. Chim. Acta 2001, 321, 56-62.

51. Huffman, D. L.; O'Halloran, T. V.; Annu. Rev. Biochem. 2001, 70, 677-701.
52. Lee, J.; Pena, M. M.; Nose, Y.; Thiele, D. J. J. Biol. Chem. 2007, 277, 380-4387.

53. Markossian, K. A.; Kurganov, B. I. Biochemistry (Moscow) 2003 , $68,827-837$.

54. Rubinstein, L. V.; Shoemaker, R. H.; Paull, K. D.; Simon, R. M.; Tosini, S.; Skehan, P.; Scudiero, D. A.; Monks, A.; Boyd, M. R. J. Natl. Cancer. Inst. 1990, 82, 1113-1118.

55. Skehan, P.; Storeng, R.; Scudiero, D.; Monks, A.; McMahon,; Vistica, D.; Warren, J. T.; Bokesch, H.; Kenney, S.; Boyd, M. R. J. Natl. Cancer. Inst. 1990, 82, 1107-1112.

56. AnalystSoft, Robust Business Solutions, StatPlus 2005 Professional Build Version 3.5.3.0, 2005.

57. SHELX-97-2 [Includes SHELXS97, SHELXL97, CIFTAB (and SHELXA)] - Programs for Crystal Structure Analysis (Release 97-2). Sheldrick, G. M., Institüt für Anorganische Chemie der Universität, Tammanstrasse 4, D-3400 Göttingen, Germany, 1998.

58. INTERNATIONAL TABLES VOL. A - Hahn, T. Ed., International Tables for Crystallography, Volume A, Kluwer Academic Publishers, Dordrecht, The Netherlands, 1995.

59. L. J. Farrugia, J. Appl. Cryst., 1999, 32, 837. 